\title{
Bilateral scrotoshisis a rare entity: case report
}

\author{
Shazia Perveen*, Mishraz Shaikh and Sajid Ali
}

\begin{abstract}
Background: Scrotoschisis is a rare anomaly in which the testis is lying outside scrotum congenitally. Only few cases have been reported in literature under different names most of which are unilateral. We have found only one case of bilateral scrotoschisis in literature.

Case presentation: Newborn presented to us after normal term twin delivery as a case of bilateral scrotoschisis in which both testes were lying outside the scrotum congenitally. Baby underwent uneventful bilateral orchiopexy and was discharged home the next day.

Conclusion: Scrotoschisis is a very rare genital anomaly with only a few cases reported in literature. This report would add to the literature which would help in studying the exact mechanism and embryopathogenesis of this anomaly which is not known yet.
\end{abstract}

Keywords: Bilateral scrotoschisis, Extracorporeal testicular ectopia, Testicular extrusion

\section{Background}

Scrotoschisis is an extremely rare condition that present congenitally in which one or both testes are lying outside the scrotum through a scrotal wall defect. Owing to no standardized term, people have used different terms for this condition like extracorporeal testicular ectopia, testicular exstrophy, and testicular extrusion $[1,2]$. There are only a few case reports in literature, and almost all of them are unilateral cases $[3,4]$. To the best of our knowledge, only one case of bilateral scrotoschisis has been reported till date [5]. We are reporting a case of bilateral scrotoschisis in a term male neonate with twin delivery.

\section{Case presentation}

Eight-hour-old baby boy, weighing $1.6 \mathrm{~kg}$, term twin born to gravida 1, para 1 mother, presented to emergency with both testes lying outside the scrotum since birth. Mother was 35 years old and had normal antenatal scans throughout pregnancy, but developed pregnancy-induced

\footnotetext{
* Correspondence: dr.shaz89@gmail.com

Department of Pediatric Surgery, National Institute of Child Health, Jinnah Sindh Medical University, Karachi, Pakistan
}

hypertension for which she was on antihypertensive drugs; she gave birth to twins via caesarean section, and the other female twin was normal and good weight. Mother expired $6 \mathrm{~h}$ post delivery after sudden onset chest pain as described by the attendant, exact cause of which is not known as the baby was delivered in a periphery setup so exact details could not be determined.

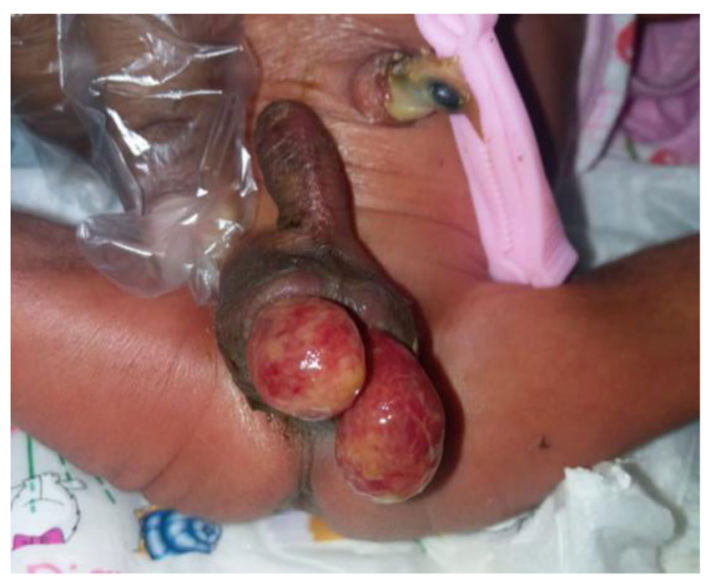

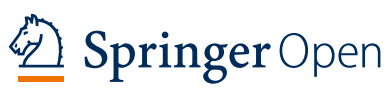

(c) The Author(s). 2021 Open Access This article is licensed under a Creative Commons Attribution 4.0 International License, which permits use, sharing, adaptation, distribution and reproduction in any medium or format, as long as you give appropriate credit to the original author(s) and the source, provide a link to the Creative Commons licence, and indicate if changes were made. The images or other third party material in this article are included in the article's Creative Commons licence, unless indicated otherwise in a credit line to the material. If material is not included in the article's Creative Commons licence and your intended use is not permitted by statutory regulation or exceeds the permitted use, you will need to obtain permission directly from the copyright holder. To view a copy of this licence, visit http://creativecommons.org/licenses/by/4.0/. 
On examination, the baby was active, pink with good cry, with an Apgar score of 10/10, having heart rate of 140 beat per minute, respiratory rate 46 breath per minute with oxygen saturation of $99 \%$ on room air. Genital examination showed normal penis with normal urethral opening, bilaterally scrotum was well developed, with rugosities and pigmentation. Both testes were exposed and hanging outside vertically through two transverse anterior scrotal wall defects on both sides of median raphe, with healthy edges; both testes were pink and healthy but edematous due to prolonged exposure; midline raphe was intact with separate spacious testicular compartments. We could not appreciate any gubernacular attachment to testis or scrotum. The rest of the examination was normal.

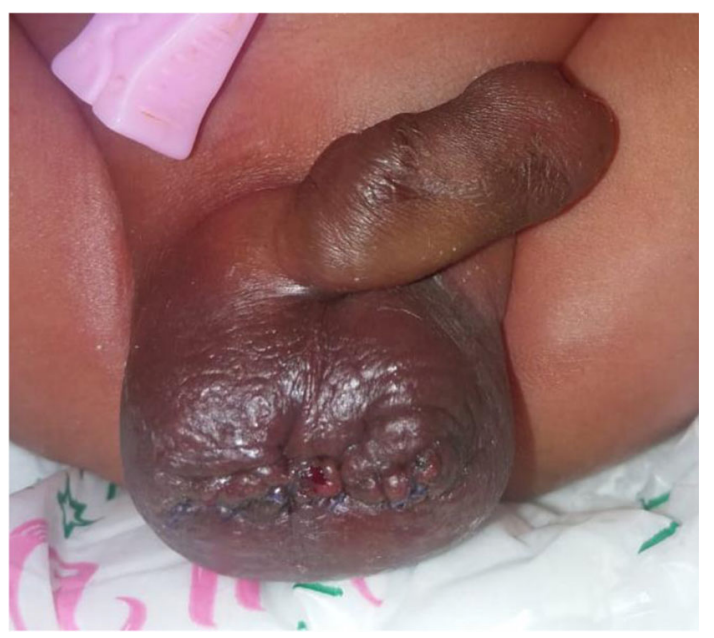

Baby was kept Nil per oral, on fluids, and prophylactic antibiotic injection cefotaxime $80 \mathrm{mg} \mathrm{q} 12 \mathrm{~h}$. Laboratory parameters were within normal range with hemoglobin of $21.2 \mathrm{~g} / \mathrm{dl}$, leucocyte count of $9 \times 10^{9} / \mathrm{L}$, and platelet count $159 \times 10^{9} / \mathrm{L}$. Informed consent was taken from the father as well as permission was taken from hospital's institutional ethical review board. Surgery was planned for testicular placement into scrotum. Baby was admitted to surgical unit with diagnosis of bilateral scrotoschisis.

Under general anesthesia, endotracheal tube passed, and the patient kept in supine position. Testicular adhesions with scrotal wall were bluntly taken down, scrotal pouch was created, and testis put back one by one easily inside the pouch taking care of not twisting them. Testicular fixation was done with interrupted sutures to prevent torsion of the testes, midline raphe was reconstructed by anchoring the midline prominent tissue to anterior wall, and scrotal skin was closed with absorbable vicryl mattress sutures. Postoperatively, baby had smooth recovery, was orally allowed, and gradually progressed to adlib feed by next day and discharged home. On the two follow-ups in outpatient department, baby was stable, and wound was clean and healing with both the testes palpable within scrotum.

\section{Discussion}

This case is second of its kind that is being reported, where both the testis were lying outside the scrotum; the first case reported by ameh [5] also had torsion of right testis which needed orchidectomy which was not the case in our patient. Scrotoschisis is sometimes described as a form of testicular ectopia where the testis is lying extracorporeal. Although the embryogenesis of this condition is not clear but different theories have been put forward. A gubernacular defect was advocated by Von der Leyen [6] to explain his case of inguinal testicular exstrophy. He suggested that the skin defect could result from the "penetrating power" of the gubernaculum, assuming that in utero this structure has phagocytic activity. Gongaware [7] who reported another case of scrotoschisis have suggested that extracorporeal testicular ectopia arise due to a scrotal defect, allowing the evisceration of the testis and question the role of gubernacular regression in the descent of the testis into the scrotum.

There are two cases reporting scrotoschisis associated with meconium periorchitis $[8,9]$ where spontaneous intrauterine perforation of the gastrointestinal tract causes leakage of meconium into peritoneal cavity and through patent processus vaginalis trickling down into scrotum and producing inflammatory response which eventually lead to rupture of anterior scrotal wall causing exposure of the testicles. However in our case, there was no intra-abdominal pathology. Lais [10] proposed that external mechanical compression of the scrotal wall played the major role in causing the skin defect with consequent testicular extrusion as in his case patient had arthrogryposis. In our case, this was a twin pregnancy, so the possibility of external compression by healthy twin causing skin defect is likely; however, the exact cause of this anomaly is not known yet.

\section{Conclusion}

Our case of bilateral scrotoschisis would add to the literature so as to help in studying the exact mechanism and embryopathogenesis of this anomaly which is not known yet.

\section{Acknowledgements}

Not applicable.

\section{Authors' contributions}

SP managed the child, operated, and wrote down the case; MS assisted and supervised in operating upon the child; and SI did literature review. All authors have read and approved the manuscript. 


\section{Funding}

Not applicable.

\section{Availability of data and materials}

Available upon request.

\section{Ethics approval and consent to participate}

Approval was taken from the "Institutional Ethical Review Board, National Institute of Child Health Karachi, Pakistan."

\section{Consent for publication}

Written informed consent for publication was obtained from patient's father as the patient was less than 16 years old.

\section{Competing interests}

Authors have no competing interests.

Received: 10 June 2020 Accepted: 9 December 2020

Published online: 15 February 2021

\section{References}

1. Togami J, Radhakrishnan J. Testicular extrusion due to scrotoschisis. Urology. 2002 Dec 1;60(6):1112.

2. Kella N, Asif M, Kumar M, Laghari F, Qureshi MA. Congenital extrusion of testis (scrotoschisis). J Coll Physicians Surg Pak. 2014;24(11, Suppl. 3):S243-4.

3. Jesus LE, Dekermacher S, Abikair Filho J, Rocha LJ. Scrotoschisis: an extremely rare congenital uropathy. Urology. 2012;79(1):219-21.

4. Shukla RM, Mandal KC, Roy D, Patra MP, Mukhopadhyay B. Scrotoschisis: an extremely rare congenital anomaly. J Indian Assoc Pediatr Surg. 2012;17(4): 176.

5. Ameh EA, Amoah JO, Awotula OP, Mbibu HN. Scrotoshisis, bilateral extracorporeal testicular ectopia and testicular torsion. Pediatric surgery international. 2003 Aug 1;19(6):497-8.

6. DER VON LE. A RARE CONGENITAL MALPOSITION OF THE TESTIS. Der Chirurg. Zeitschrift fur alle Gebiete der operativen Medizen. 1963;34:521-2.

7. Gongaware RD, Sussman AM, Kraebber DM, Michigan S. Scrotoschisis as a mechanism for extracorporeal testicular ectopia. Journal of pediatric surgery. 1991 Dec 1;26(12):1430-1.

8. Kojori F, DeMaria J. Scrotoschisis associated with meconium periorchitis. Journal of pediatric urology. 2007 Oct 1;3(5):415-6.

9. DeRoo SE, Lumpkins KM, El-Metwally DE. Scrotoschisis in a neonate with meconium peritonitis and periorchitis. J Neonatal Perinatal Med. 2016;9(1): 107-12.

10. Lais A, Serventi P, Caione P, Ferro F. Arthrogryposis as a possible mechanism of scrotoschisis acquired in utero. Pediatr Surg Int. 1994;9(8):605-6.

\section{Publisher's Note}

Springer Nature remains neutral with regard to jurisdictional claims in published maps and institutional affiliations.

\section{Submit your manuscript to a SpringerOpen ${ }^{\mathcal{O}}$ journal and benefit from:}

- Convenient online submission

- Rigorous peer review

- Open access: articles freely available online

- High visibility within the field

- Retaining the copyright to your article 